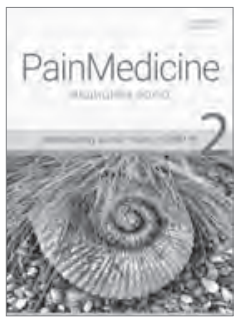

\title{
Лечение и профилактика изменений шейного отдела позвоночника у студентов
}

\author{
Якименко Е. А., Кравчук О. Е., Богдан Н. М., Гриценко М. В., Мазниченко Е. А., \\ Мариновская И. В.
}

Одесский национальный медицинский университет, г. Одесса, Украина

\begin{abstract}
Актуальность. В настоящее время среди студентов распространенными жалобами являются утомляемость, головокружение, боли в области шейного отдела позвоночника, эмоциональная напряженность.
\end{abstract}

Цель исследования. Изучить влияние лечебных мероприятий на состояние шейного отдела позвоночника и состоятельность кровообращения в вертебробазилярной зоне у студентов.

Материалы и методы. Группа наблюдения представлена 100 студентами в возрасте от 17 до 23 лет, из них мужчин и женщин соответственно 73 и 27. Был разработан опросник, где отражались основные жалобы и данные относительно образа жизни студентов. Всем лицам было проведено дуплексное сканирование брахиоцефальных сосудов, рентгенография шейного отдела позвоночника в 2-х проекциях, исследование состояния глазного дна. Проведена терапия хондропротекторами (глюкозамин гидрохлорид в комбинации с хондроитином сульфатом в дозе 1500 мг и 1200 мг/сут), продолжительность 30 дней, ницерголин 30 мг/сут в течение 1 мес, фонофрез карипаина на область шейного отдела позвоночника в количестве 20 процедур, комплекс специальных упражнений для шейного отдела позвоночника в течение 1 месяца.

Результаты исследования и их обсуждение. В результате проведенных исследований у $55 \%$ лиц наблюдались жалобы на снижение умственной работоспособности, головокружение, головные боли и т.д. Рентгенологически определены изменения шейного отдела позвоночника в виде начальных проявлений остеохондроза, выпрямление шейного лордоза. По данным дуплексного исследования брахиоцефальных сосудов опреде- лены у $35 \%$ явления нарушения венозного оттока из полости черепа, асимметрия кровотока с явлениями экстраваскулярной компрессии, наклонность к ангиоспазму. У этих же лиц на глазном дне определены сужения артериальных сосудов, некоторое расширение вен. В результате проведенного комплексного лечения определено субъективное улучшение общего состояния (уменьшение головных болей и головокружений, психоэмоциональной неустойчивости). По данным дуплексного исследования в $100 \%$ случаев наблюдалось улучшение кровотока (уменьшение явлений венозного застоя, асимметрии кровотока, наклонности к ангиоспазму). По данным рентгенологического исследования - появление шейного лордоза. При исследовании глазного дна - уменьшение явлений ангиоспазма и венозного застоя.

Выводы. Комплескное лечение в сочетании медикаментозной терапии и фонофореза карипаином оказывает положительные эффекты и может быть терапией выбора у данной категории пациентов.

Перспективы дальнейших исследований. В дальнейшем этим лицам рекомендованы повторные курсы медикаментозной терапии в сочетании с фонофорезом карипаина под контролем рентгенологических данных. Постоянные занятия лечебной физкультурой, ограничение избыточных нагрузок на шейный отдел позвоночника (интенсивные занятия спортом), ограничение времени работы за компьютером (чередование с физическими упражнениями).

Ключевые слова: студенты, шейный отдел позвоночника, лечение, профилактика.

Конфликт интересов - нет. 